\title{
Yapı Makinaları Kullanımında Karşılaşılan İş Kazalarının Azaltılmasına Yönelik Değerlendirmeler ve Öneriler
}

\author{
Halil Yakar ${ }^{* 1}$, Ertuğrul Taçgın²
}

\section{ÖZ}

Sektörde işçi sağlığı ve iş güvenliği yönünden yapılan araştırmalar ve istatistikler dikkatli bir biçimde incelenecek olursa yapı makinaları kaynaklı kazaların ne denli ciddi sonuçlara yol açtığı daha rahat gözlenebilecektir. Yapı makinaları kaynaklı iş kazaları, sonuçları itibari ile sektördeki diğer iş kazaları ile karşılaştırıldığında ölümle ya da sürekli iş görmemezlikle sonuçlanan kazalar bakımından üst sıralarda yer almaktadır. Yapı makinalarının verimlilikte sağladığı avantajların yanı sıra işçi sağlığı ve iş güvenliği bakımından getirdiği risklere bağlı dezavantajları da değerlendirilmelidir. İnşaat sahalarında kullanılan bu makinaların doğurduğu, en ufak bir dikkatsizlikte ciddi sonuçları olan bu iş kazalarından en az hasarla kurtulabilmek için bir takım tedbirler almak zaruri olmuştur. En önemli tedbirler arasında şantiye trafik ve iş güvenliği planının hazırlanması, bu konuda sorumlulukların dağıtılması ve ayrıca operatörlere ve işçilere yönelik eğitimler ile makinaların bakım ve onarımlarının zamanında yapılması gelmektedir. Bu çalışmada öncelikli olarak Türkiye'deki iş kazalarında mevcut olan istatiksel veri bilgilendirmeleri üzerinde durulmuştur. Seçilen saha çalışması sonuçlarını da kullanarak iş makinalarını kullanan operatörlerin eğitimlerinin ve makine hakkındaki bilgi sahibi olmalarının ne kadar önemli olduğuna dikkat çekilmeye çalışılmıştır. Son olarak da operatör eğitimi konusunda Türkiye'deki eksikliğe vurgu yapılmıştır.

Anahtar Kelimeler: İş makinası kazası, inşaat sektörü, operatör hataları ve kaza, yol çalışmaları güvenliği

\section{Construction Machinery Use Evaluations and Recommendations for Reducing Occupational Accidents}

\begin{abstract}
If the researches and statistics about occupational health and safety in the sector are examined carefully, it can be observed that the serious consequences of the accidents caused by the construction machinery cause more serious results. Occupational accidents caused by construction machines are at the top of the accidents due to deaths or permanent inefficiencies compared to other occupational accidents in the sector. The disadvantages of construction machines due to their advantages in terms of productivity as well as the risks of occupational health and safety should be evaluated. It has been necessary to take some measures in order to be able to get rid of these work accidents with the least damage caused by these machines used in construction sites, which have serious consequences in the slightest carelessness. The most important measures include the preparation of the construction site traffic and work safety plan, the distribution of responsibilities in this regard, as well as the training of operators and workers and the maintenance and repair of the machines on time. This study focused on existing statistical data to inform priority in work accidents in Turkey. By using the results of the selected field work, it has been tried to draw attention to the importance of the trainings of the operators using the machines and their knowledge about the machine. Finally, the emphasis on the lack of operator training has been done in Turkey.
\end{abstract}

Keywords: Construction machinery accidents, construction sector, operator faults and accidents, road work safety

\footnotetext{
" İletișim Yazarı

Geliș/Received

03.01.2019

Kabul/Accepted

27.08.2019

1 Marmara Üniversitesi, Fen Bilimleri Enstitüsü, İş Güvenliği Ana Bilim Dalı, İstanbul hpmsyakar@gmail.com, ORCID: 0000-0003-3495-7962

2 Marmara Üniversitesi, Fen Bilimleri Enstitüsü, İş Güvenliği Ana Bilim Dalı, İstanbul ertugrul.tacgin@marmara.edu.tr, ORCID: 0000-0003-2863-2758
} 


\section{GÍRİŞ}

Dünya ekonomisinin ve ülkemiz ekonomisinin temel ve en büyük sektörlerinden olan yapı sektörü, bünyesinde en önemli bileşen olarak iş makinalarını barındırmaktadır. $\mathrm{Bu}$ bağlamda, iş makinalarının sebep olduğu kazalar, iş güvenliği kavramının öneminin, işveren ve çalışan merkezli hale getirilmesi ile azaltılabilir ve büyük ölçüde önlenebilir.

İnşaat sektörümüz iş kazalarının sayısal çokluğu ve ağır sonuçları bakımından Türkiye'deki iş kolları arasında ilk üç iş kolundan biridir. [1] [12] [13] [14] Hedef, inşaat işyerlerinde meslek hastalığı oluşmaması, iş kazası, yaralanma, çalışanlara zarar veren kötü olaylar, etkenler ve maddi kayıpların olmaması veya bu tip olumsuzlukların asgari düzeye indirilmesi için, riskleri ve alınacak önlemlerin birim sorumlularından başlayarak en alt birime kadar dağıtılması hususlarının başarıyla gerçekleştirilmesi olmalıdır. [2] Son yıllarda Türkiye'de inşaat sektöründe işçi sağlığ1 ve güvenliği konusu ön plana çıkmaktadır. Türkiye'nin Avrupa Birliği'ne girme isteği ve bu konudaki uyum çalışmaları ve inşaat sektörünün uluslararası platformda birçok projede yer alması işçi sağlığı ve güvenliği konusundaki çalışmaları olumlu yönde etkilemektedir. [3] İş kazalarının maddi kayıpları ise öyle bir boyuta ulaşmıştır ki, İngiltere'de yapılan bir çalışmaya göre 2016/2017 dönemlerinde 1 milyar pound değerimde bir bedel iş kazaları ve meslek hastalıkları kaynaklı ölüm, yaralanma, iş günü kaybı, sigorta ve sağlık masraflarına ayrılmak zorunda kalınmıştır. Bu çalışmayı 15 AB ülkesini kapsayan coğrafyaya yansıttığımızda Avrupa birliğinin gayri safi milli hasılasının \%3,3 ü olan 476 milyar Euro bedeline ulaşmaktadır. (HSE, 2017). [16] Ülkemizde gelişmiş ülkelerinin aksine, iş kazaları azalma eğiliminde olmamakla birlikte yıldan yıla dalgalanmalar görülmektedir. Bu da gerekli ve yeterli önlemlerinin alınmadığının bir göstergesidir. İş kazalarının nedenleri arasında eğitim eksikliği önemli etkenlerden birisidir. [5] Yapı makinaları kaynaklı kazaların nedenleri başka bir açıdan elde edilen veriler ışı̆̆ında incelenecek olursa kazaların yaklaşık \% 50'sinin insan hatasından kaynaklandığı görülecektir. İnsan hatasından kastedilen, sıklıkla operatörlerin yapmış olduğu hatalı davranışlar ile makinaların civarında çalışanların gerekli önlemleri almadan çalışma yapmasını kapsamaktadır. [6]

Sektördeki iş kazaları, genellikle kişisel koruyucu kullanmamaktan kaynaklanmakta gibi görünse de, kazaların esas nedeni organizasyonel ve yönetsel hatalardır. İnşaat şirketleri, aldıkları işin neredeyse tamamını alt yüklenici firmalara yaptırmaktadır. Bu firmaların işçilerinin, şantiyece verilen eğitimi algılayıp uygulayacak düzeyde öğrenimleri bulunmaması, çoğu işi götürü aldıkları için hızlı ve uzun süreli (yaklaşık 10 saatin üstünde) çalıştırılmaları kazalara zemin hazırlamaktadır. [7] İş Makinesi Bakım ve Onarımcısı (Seviye 4) çalışmalarını her türlü kapalı ve açık alanlarda gerçekleştirir. Çalışma ortamının olumsuz koşulları arasında kirli, tozlu, gürültülü ve yağlı ortam, egzoz dumanına, hidrolik basınca ve hava basıncına maruz kalma sayılabilir. Mesleğin icrası esnasında iş sağlığı ve güvenliği önlemlerini gerektiren kaza ve yaralanma 
riskleri bulunmaktadır. Risklerin tamamen ortadan kaldırılamadığı durumlarda ise işveren tarafından sağlanan uygun kişisel koruyucu donanımı kullanarak çalışır. [8] Yapı makinaları konusunda yapılan literatür taramaları sonucunda da yapı makinalarıyla ilgili olası iş kazalarını önleyebilmek adına alınması gereken önlemleri operatör eğitimi, tüm işçilere yönelik yapılan genel eğitimler ve yapı makinalarının bakım ve onarımı olarak üç ana başlıkta derlemek mümkündür.[9] Riskleri azaltmak ve kontrol edebilmek, etkili bir iş sağlığı ve güvenliğinin en önemli parçasıdır. [10] [11]

\section{2. İSTATISTIKKSEL VERILER}

İş kazası sonucu her yıl çok sayıda inşaat işçisi yaşamını yitirmekte veya sakat kalmakta sosyal ve ekonomik bir fikir vermek amacıyla, Sosyal Güvenlik Kurumu'nun

Tablo 1. Türkiye Genelinde ve İnşaat Sektöründe 1995-2017 Döneminde Meydana Gelen İş Kazası Sayıları [1]

\begin{tabular}{|c|c|c|c|c|}
\hline Yillar & $\begin{array}{l}\text { Meslek hastallı̆̆ } \\
\text { sayısı }\end{array}$ & $\begin{array}{c}\text { Meslek hastalığı } \\
\text { sebebiyle ölüm sayısı }\end{array}$ & $\begin{array}{l}\text { İş kazası sebebiyle } \\
\text { ölüm sayısı }\end{array}$ & $\begin{array}{l}\text { İK ve MH sonucu } \\
\text { ölüm sayısı }\end{array}$ \\
\hline 1995 & 975 & 121 & 798 & 919 \\
\hline 1996 & 1.115 & 196 & 1.296 & 1.492 \\
\hline 1997 & 1.055 & 191 & 1.282 & 1.473 \\
\hline 1998 & 1.400 & 158 & 1.094 & 1.252 \\
\hline 1999 & 1.025 & 168 & 1.165 & 1.333 \\
\hline 2000 & 803 & 6 & 1.167 & 1.173 \\
\hline 2001 & 883 & 6 & 1.002 & 1.008 \\
\hline 2002 & 601 & 6 & 872 & 878 \\
\hline 2003 & 440 & 1 & 810 & 811 \\
\hline 2004 & 384 & 2 & 841 & 843 \\
\hline 2005 & 519 & 24 & 1.072 & 1.096 \\
\hline 2006 & 574 & 9 & 1.592 & 1.601 \\
\hline 2007 & 1.208 & 1 & 1.043 & 1.044 \\
\hline 2008 & 539 & 1 & 865 & 866 \\
\hline 2009 & 429 & 0 & 1.171 & 1.171 \\
\hline 2010 & 533 & 10 & 1.444 & 1.454 \\
\hline 2011 & 697 & 10 & 1.700 & 1.710 \\
\hline 2012 & 395 & 1 & 744 & 745 \\
\hline 2013 & 371 & 0 & 1360 & 1.360 \\
\hline 2014 & 494 & 0 & 1626 & 1.626 \\
\hline 2015 & 510 & 0 & 1252 & 1252 \\
\hline 2016 & 597 & 0 & 1405 & 1405 \\
\hline 2017 & 691 & 0 & 1633 & 1633 \\
\hline
\end{tabular}


(SGK) 1995-2017 yılları arasındaki istatistiklerinden elde edilen veriler Tablo 1'de gösterilmiş.

İncelenen iş kazaları oluş biçimlerine göre gruplandırılmış ve elde edilen ana tipler ve bunların sayısal dağılımları Tablo 2'de gösterilmiştir.

Genel olarak İncelenen kaza tipleri yapılan inşaat uygulamasının niteliğine göre doğal olarak farklı dağılımlar göstermektedir. "Şantiye Türü” olarak ifade edilen farklı uygulama alanlarında ön plana çıkan kaza tiplerinin bilinmesinde yarar olacağı düşünce-

Tablo 2. İncelenen 5239 İş Kazasının "Kaza Tipleri”ne Göre Dağılımı (Ana Gruplar) [1]

\begin{tabular}{|l|l|c|c|c|c|c|c|}
\hline \multirow{2}{*}{ No. } & Ana Gruplar & \multicolumn{2}{|c|}{ Ölüm } & \multicolumn{2}{c|}{ Yaralanma } & \multicolumn{3}{c|}{ Toplam } \\
\cline { 2 - 8 } & Kaza Tipi & Sayı & $\%$ & Sayı & $\%$ & Sayı & $\%$ \\
\hline 1 & Insan Düşmesi & 1028 & 42,9 & 934 & 32,9 & 1962 & 37,4 \\
\hline 2 & Malzeme Düşmesi & 251 & 10,5 & 278 & 9,8 & 529 & 10,1 \\
\hline 3 & Malzeme Sıçraması & 10 & 0,4 & 211 & 7,4 & 221 & 4,2 \\
\hline 4 & Kazı Kenarının Göçmesi & 138 & 5,8 & 53 & 1,9 & 191 & 3,6 \\
\hline 5 & Yapı Kısmının Çökmesi & 167 & 7,0 & 73 & 2,6 & 240 & 4,6 \\
\hline 6 & & & & & & & 373 \\
\hline 7 & Elektrik Çarpması & 293 & 12,2 & 80 & 2,8 & 7,1 \\
\hline 8 & Yapı Makinası Kazaları & 50 & 0,2 & 82 & 2,9 & 132 & 2,5 \\
\hline 9 & Uzuv Kaptırma & 206 & 8,6 & 97 & 3,4 & 303 & 5,8 \\
\hline 10 & Uzuv Sıkışması & 1 & 0,0 & 604 & 21,3 & 605 & 11,5 \\
\hline 11 & El Aleti Ille Ele Vurma & 1 & 0,0 & 200 & 7,0 & 201 & 3,8 \\
\hline 12 & Sivri Uçlu Keskin Ken Cis. Yara. & 0 & 0,0 & 75 & 2,6 & 75 & 1,4 \\
\hline 13 & Şantiye içi Trafik Kazaları & 168 & 7,0 & 38 & 1,3 & 206 & 3,9 \\
\hline 14 & Diğer Tip kazalar & 85 & 3,5 & 74 & 2,6 & 159 & 3,0 \\
\hline & Toplam & 2398 & 100,0 & $\mathbf{2 8 4 1}$ & 100,0 & $\mathbf{5 2 3 9}$ & 100,0 \\
\hline
\end{tabular}

Tablo 2a.Tablo 2'nin Güncellenmiş Hali, 2014 Verilerine Göre [10]

\begin{tabular}{|l|c|c|c|c|}
\hline Kaza Tipi & Ölüm & $\%$ & Yaralanma & $\%$ \\
\hline İnsan Düşmesi & 1120 & 43,7 & 978 & 33,3 \\
\hline Elektrik Çarpması & 303 & 11,8 & 86 & 2,9 \\
\hline Malzeme Düşmesi & 269 & 10,5 & 313 & 10,7 \\
\hline Yapı Makinalarındaki Kazalar & 229 & 8,9 & 115 & 3,9 \\
\hline Yapı Kısmının Çökmesi & 174 & 6,8 & 90 & 3,1 \\
\hline Şantiye İ̧i Trafik Kazaları & 171 & 6,7 & 41 & 1,4 \\
\hline
\end{tabular}


siyle önemli inşaat uygulamalarından bina, yol, kanal, tünel şantiyelerindeki kaza tiplerinin dağılımı Tablo 3 verilmiş ve dikkati çeken bazı bulgular üzerinde durulmuştur.

“Şantiye Türü” olarak ifade edilen farklı uygulama alanlarında ön plana çıkan kaza tiplerinin bilinmesinde yarar olacağı düşüncesiyle önemli inşaat uygulamalarından yol şantiyelerindeki kaza tiplerinin dağılımı Tablo 4 verilmiş ve dikkati çeken bazı bulgular üzerinde durulmuştur.

"Şantiye Türü” olarak ifade edilen farklı uygulama alanlarında ön plana çıkan kaza tiplerinin bilinmesinde yarar olacağı düşüncesiyle önemli inşaat uygulamalarından kanal şantiyelerindeki kaza tiplerinin dağılımı Tablo 5 verilmiş ve dikkati çeken bazı bulgular üzerinde durulmuştur.

“Şantiye Türü” olarak ifade edilen farklı uygulama alanlarında ön plana çıkan kaza tiplerinin bilinmesinde yarar olacağı düşüncesiyle önemli inşaat uygulamalarından Tünel şantiyelerindeki kaza tiplerinin dağılımı Tablo 6 verilmiş ve dikkati çeken bazı bulgular üzerinde durulmuştur.

2014-2015 yılları aylara göre iş kazalarının aylara göre dağılımlarına bakmak istediğimizde yıl içini üç eşit döneme bölmemiz bize dönemsel kaza oranlarını verecektir. Bu bilgiyi Tablo 7'de görmekteyiz.

Tablo 3. Bina İnşaatı Şantiyelerindeki Kaza Tipleri [1]

\begin{tabular}{|l|l|c|c|c|c|c|c|}
\hline \multirow{2}{*}{ No. } & \multicolumn{1}{|c|}{ Bina İnşaatı Şantiyeleri } & \multicolumn{2}{c|}{ Ölüm } & \multicolumn{2}{c|}{ Yaralanma } & \multicolumn{2}{c|}{ Toplam } \\
\cline { 2 - 8 } & \multicolumn{1}{|c}{ Kaza Tipi } & Sayı & $\%$ & Sayı & $\%$ & Sayı & $\%$ \\
\hline 1 & İnsan Düşmesi & 880 & 57,3 & 822 & 42,8 & 1702 & 49,2 \\
\hline 2 & Malzeme Düşmesi & 150 & 9,8 & 169 & 8,8 & 319 & 9,2 \\
\hline 3 & Malzeme Sıçraması & 2 & 0,1 & 129 & 6,7 & 131 & 3,8 \\
\hline 4 & Kazı Kenarının Göçmesi & 60 & 3,9 & 21 & 1,1 & 81 & 2,3 \\
\hline 5 & Yapı Kısmının Çökmesi & 105 & 6,8 & 53 & 2,8 & 158 & 4,6 \\
\hline 6 & Elektrik Çarpması & 255 & 16,6 & 59 & 3,1 & 314 & 9,1 \\
\hline 7 & Patlayıcı Madde Kazaları & 4 & 0,3 & 19 & 1,0 & 23 & 0,7 \\
\hline 8 & Yapı Makinası Kazaları & 33 & 2,1 & 24 & 1,2 & 57 & 1,6 \\
\hline 9 & Uzuv Kaptırma & 1 & 0,1 & 420 & 21,9 & 421 & 12,2 \\
\hline 10 & Uzuv Sıkışması & 0 & 0,0 & 90 & 4,7 & 90 & 2,6 \\
\hline 11 & El Aleti İle Ele Vurma & 0 & 0,0 & 26 & 1,4 & 26 & 0,8 \\
\hline 12 & Sivri Uçlu Keskin Ken Cis. Yara. & 0 & 0,0 & 38 & 2,0 & 38 & 1,1 \\
\hline 13 & Şantiye içi Trafik Kazaları & 22 & 1,4 & 8 & 0,4 & 30 & 0,9 \\
\hline 14 & Diğer Tip kazalar & 23 & 1,5 & 44 & 2,3 & 67 & 1,9 \\
\hline & Toplam & 1535 & 100,0 & 1922 & 100,0 & 3457 & 100,0 \\
\hline
\end{tabular}


Tablo 4. Yol İnşaatı Şantiyelerindeki Kaza Tipleri [1]

\begin{tabular}{|l|l|c|c|c|c|c|c|}
\hline \multirow{2}{*}{ No. } & Yol İnşaatı Şantiyeleri & \multicolumn{2}{|c|}{ Ölüm } & \multicolumn{2}{c|}{ Yaralanma } & \multicolumn{2}{c|}{ Toplam } \\
\cline { 2 - 8 } & Kaza Tipi & Sayı & $\%$ & Sayı & $\%$ & Sayı & $\%$ \\
\hline 1 & İnsan Düşmesi & 8 & 3,5 & 20 & 7,7 & 28 & 5,8 \\
\hline 2 & Malzeme Düşmesi & 15 & 6,6 & 18 & 6,9 & 33 & 6,8 \\
\hline 3 & Malzeme Sıçraması & 1 & 0,4 & 29 & 11,2 & 30 & 6,2 \\
\hline 4 & Kazı Kenarının Göçmesi & 4 & 1,8 & 5 & 1,9 & 9 & 1,9 \\
\hline 5 & Yapı Kısmının Çökmesi & 1 & 0,4 & 1 & 0,4 & 2 & 0,4 \\
\hline 6 & Elektrik Çarpması & 1 & 0,4 & 3 & 1,2 & 4 & 0,8 \\
\hline 7 & Patlayıcı Madde Kazaları & 24 & 10,6 & 27 & 10,4 & 51 & 10,5 \\
\hline 8 & Yapı Makinası Kazaları & 90 & 39,6 & 33 & 12,7 & 123 & 25,3 \\
\hline 9 & Uzuv Kaptırma & 0 & 0,0 & 53 & 20,5 & 53 & 10,9 \\
\hline 10 & Uzuv Sıkısması & 0 & 0,0 & 37 & 14,3 & 37 & 7,6 \\
\hline 11 & El Aleti Ille Ele Vurma & 0 & 0,0 & 4 & 1,5 & 4 & 0,8 \\
\hline 12 & Sivri Uçlu Keskin Ken Cis. Yara. & 0 & 0,0 & 11 & 4,2 & 11 & 2,3 \\
\hline 13 & Şantiye icci Trafik Kazaları & 74 & 32,6 & 15 & 5,8 & 89 & 18,3 \\
\hline 14 & Diğer Tip kazalar & 9 & 4,0 & 3 & 1,2 & 12 & 2,5 \\
\hline & Toplam & 227 & 100,0 & 259 & 100,0 & 486 & 100,0 \\
\hline
\end{tabular}

Tablo 5. Kanal İnşaatı Şantiyelerindeki Kaza Tipleri [1]

\begin{tabular}{|l|l|c|c|c|c|c|c|}
\hline \multirow{2}{*}{ No. } & \multicolumn{1}{|c|}{ Kanal İş̧aatı Şantiyeleri } & \multicolumn{2}{|c|}{ Ölüm } & \multicolumn{2}{c|}{ Yaralanma } & \multicolumn{2}{c|}{ Toplam } \\
\cline { 2 - 8 } & \multicolumn{1}{|c|}{ Kaza Tipi } & Sayı & $\%$ & Sayı & $\%$ & Sayı & $\%$ \\
\hline 1 & Insan Düşmesi & 19 & 12,9 & 8 & 7,6 & 27 & 10,7 \\
\hline 2 & Maızeme Düşmesi & 11 & 7,5 & 13 & 12,4 & 24 & 9,5 \\
\hline 3 & Malzeme Sıçraması & 1 & 0,7 & 12 & 11,4 & 13 & 5,2 \\
\hline 4 & Kazı Kenarının Göçmesi & 68 & 46,3 & 13 & 12,4 & 81 & 32,1 \\
\hline 5 & Yapı Kısmının Çökmesi & 2 & 1,4 & 0 & 0,0 & 2 & 0,8 \\
\hline 6 & Elektrik Çarpması & 5 & 3,4 & 1 & 1,0 & 6 & 2,4 \\
\hline 7 & Patlayıcı Madde Kazaları & 8 & 5,4 & 11 & 10,5 & 19 & 7,5 \\
\hline 8 & Yapı Makinası Kazaları & 13 & 8,8 & 7 & 6,7 & 20 & 7,9 \\
\hline 9 & Uzuv Kaptırma & 0 & 0,0 & 19 & 18,1 & 19 & 7,5 \\
\hline 10 & Uzuv Sıkışması & 0 & 0,0 & 13 & 12,4 & 13 & 5,2 \\
\hline 11 & El Aleti İle Ele Vurma & 0 & 0,0 & 2 & 1,9 & 2 & 0,8 \\
\hline 12 & Sivri Uçlu Keskin Ken Cis. Yara. & 0 & 0,0 & 3 & 2,9 & 3 & 1,2 \\
\hline 13 & Şantiye içi Trafik Kazaları & 13 & 8,8 & 3 & 2,9 & 16 & 6,3 \\
\hline 14 & Diğer Tip kazalar & 7 & 4,8 & 0 & 0,0 & 7 & 2,8 \\
\hline & Toplam & 147 & 100,0 & 105 & 100,0 & $\mathbf{2 5 2}$ & 100,0 \\
\hline
\end{tabular}


Tablo 6. Tünel İnşaatı Şantiyelerindeki Kaza Tipleri [1]

\begin{tabular}{|l|l|c|c|c|c|c|c|}
\hline \multirow{2}{*}{ No. } & Tünel İnşaatı Şantiyeleri & \multicolumn{2}{|c|}{ Ölüm } & \multicolumn{2}{c|}{ Yaralanma } & \multicolumn{2}{c|}{ Toplam } \\
\cline { 2 - 8 } & Kaza Tipi & Sayı & $\%$ & Sayı & $\%$ & Sayı & $\%$ \\
\hline 1 & İnsan Düşmesi & 0 & 0,0 & 5 & 17,9 & 5 & 9,6 \\
\hline 2 & Malzeme Düşmesi & 15 & 62,5 & 7 & 25,0 & 22 & 42,3 \\
\hline 3 & Malzeme Sıçraması & 0 & 0,0 & 0 & 0,0 & 0 & 0,0 \\
\hline 4 & Kazı Kenarının Göçmesi & 1 & 4,2 & 0 & 0,0 & 1 & 1,9 \\
\hline 5 & Yapı Kısmının Çökmesi & 0 & 0,0 & 0 & 0,0 & 0 & 0,0 \\
\hline 6 & Elektrik Çarpması & 0 & 0,0 & 0 & 0,0 & 0 & 0,0 \\
\hline 7 & Patlayıcı Madde Kazaları & 5 & 20,8 & 3 & 10,7 & 8 & 15,4 \\
\hline 8 & Yapı Makinası Kazaları & 2 & 8,3 & 2 & 7,1 & 4 & 7,7 \\
\hline 9 & Uzuv Kaptırma & 0 & 0,0 & 3 & 10,7 & 3 & 5,8 \\
\hline 10 & Uzuv Sıkışması & 0 & 0,0 & 3 & 10,7 & 3 & 5,8 \\
\hline 11 & El Aleti İle Ele Vurma & 0 & 0,0 & 2 & 7,1 & 2 & 3,8 \\
\hline 12 & Sivri Uçlu Keskin Ken Cis. Yara. & 0 & 0,0 & 1 & 3,6 & 1 & 1,9 \\
\hline 13 & Şantiye içi Trafik Kazaları & 1 & 4,2 & 2 & 7,1 & 3 & 5,8 \\
\hline 14 & Diğer Tip kazalar & 0 & 0,0 & 0 & 0,0 & 0 & 0,0 \\
\hline & Toplam & 24 & 100,0 & 28 & 100,0 & $\mathbf{5 2}$ & 100,0 \\
\hline
\end{tabular}

Tablo 7. 2014-2018 Yılları SGK istatistiklerine Göre İş Kazalarının Meydana Geldiği Dönemler Gösterilmiştir [3], [14]

\begin{tabular}{|l|c|c|c|c|c|c|c|c|c|c|}
\hline \multirow{2}{*}{ Aylar } & \multicolumn{2}{|c|}{$\begin{array}{c}2014 \text { Yııı iş } \\
\text { Kazaları }\end{array}$} & \multicolumn{2}{|c|}{$\begin{array}{c}2015 \text { Yııı Iş } \\
\text { Kazaları }\end{array}$} & \multicolumn{2}{|c|}{$\begin{array}{c}2016 \text { Yııı iş } \\
\text { Kazaları }\end{array}$} & \multicolumn{2}{c|}{$\begin{array}{c}2017 \text { Yıı İş } \\
\text { Kazaları }\end{array}$} & \multicolumn{2}{|c|}{$\begin{array}{c}2018 \text { Yıı Iş } \\
\text { Kazaları }\end{array}$} \\
\cline { 2 - 12 } & Sayı & $\%$ & Sayı & $\%$ & Sayı & $\%$ & Sayı & $\%$ & Sayı & $\%$ \\
\hline Ocak-Nisan & 384 & $24 \%$ & 370 & $29 \%$ & 595 & $30 \%$ & 595 & $30 \%$ & 591 & $31 \%$ \\
\hline Mayıs-Ağustos & 756 & $46 \%$ & 439 & $35 \%$ & 719 & $36 \%$ & 750 & $37 \%$ & 706 & $37 \%$ \\
\hline Eylül-Aralık & 486 & $30 \%$ & 443 & $35 \%$ & 656 & $33 \%$ & 661 & $33 \%$ & 627 & $33 \%$ \\
\hline Toplam & 1626 & $100 \%$ & 1252 & $100 \%$ & 1970 & $100 \%$ & 2006 & $100 \%$ & 1924 & $100 \%$ \\
\hline
\end{tabular}

2012-2016 yılı öncesi ilk üç sene verilerinde iş kazalarının meydana geldiği iş saatleri incelemek istersek yıllara göre dağılımları aşağıdaki Tablo 8 de saat oranlarına göre dağılımını görmekteyiz. 


\begin{tabular}{|c|c|c|c|c|c|c|c|c|c|c|c|c|}
\hline \multirow{3}{*}{ ํㅠ } & 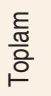 & 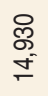 & $\begin{array}{l}\hat{ळ} \\
\text { ల్ } \\
\text { N. }\end{array}$ & $\begin{array}{l}\text { 心 } \\
\text { న్ }\end{array}$ & $\begin{array}{l}\text { षे } \\
\infty \\
\text { N }\end{array}$ & $\begin{array}{l}\text { ్ָల్ } \\
\infty \\
\infty\end{array}$ & 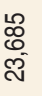 & $\begin{array}{l}\text { ర్ల్ } \\
\text { న్ }\end{array}$ & $\begin{array}{l}\bar{\alpha} \\
\bar{\sigma}\end{array}$ & 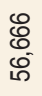 & 0 & 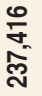 \\
\hline & $\begin{array}{l}\text { 产 } \\
\text { 岌 }\end{array}$ & 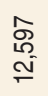 & $\begin{array}{l}\bar{\delta} \\
\bar{\sim} \\
\text {. }\end{array}$ & $\begin{array}{l}\text { \%ి } \\
\text { న్ } \\
\text { స్ }\end{array}$ & 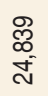 & 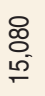 & $\begin{array}{l}\frac{0}{N} \\
\stackrel{N}{N} \\
\stackrel{N}{~}\end{array}$ & $\begin{array}{l}\widetilde{\tilde{N}} \\
\stackrel{0}{\sigma} \\
\sigma^{2}\end{array}$ & 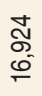 & $\frac{m}{\underset{f}{E}}$ & 0 & 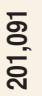 \\
\hline & 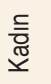 & 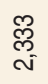 & $\begin{array}{l}\text { D్ల } \\
\text { ల' }\end{array}$ & $\begin{array}{l}\infty \\
\infty \\
\infty \\
ल^{-1}\end{array}$ & $\underset{+}{\stackrel{亠}{\sim}}$ & $\begin{array}{l}\underset{\sim}{\mathbb{N}} \\
\text { J }\end{array}$ & 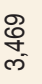 & $\begin{array}{l}\stackrel{+}{৫} \\
\stackrel{\infty}{\infty}\end{array}$ & 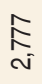 & 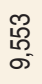 & 0 & $\begin{array}{l}\text { స్ల } \\
\text { ర్ల }\end{array}$ \\
\hline \multirow{3}{*}{ ని } & $\begin{array}{l}\frac{E}{\sigma} \\
\frac{\pi}{0} \\
\stackrel{\circ}{\circ}\end{array}$ & $\begin{array}{l}\widetilde{N} \\
\stackrel{\sim}{\sim}\end{array}$ & $\begin{array}{l}\text { ণ্ } \\
\text { ¿ } \\
\text {. }\end{array}$ & $\begin{array}{l}\text { §ิ } \\
\text { స్ }\end{array}$ & $\frac{\infty}{\frac{\infty}{ \pm}}$ & 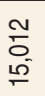 & 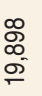 & $\frac{\stackrel{L}{\circ}}{\sigma^{\circ}}$ & $\begin{array}{l}\text { \% } \\
0 \\
0 \\
0\end{array}$ & 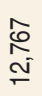 & 0 & 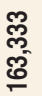 \\
\hline & 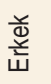 & $\begin{array}{l}0 \\
\stackrel{+}{0} \\
0 \\
0\end{array}$ & 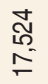 & $\begin{array}{l}\frac{m}{\sigma} \\
\sigma \\
\sigma\end{array}$ & 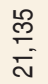 & $\begin{array}{l}\text { P্ } \\
\text { I }\end{array}$ & $\begin{array}{l}\text { న్న } \\
\text { స్ }\end{array}$ & 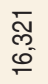 & 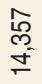 & $\begin{array}{l}\text { ष } \\
\stackrel{0}{\circ}\end{array}$ & 0 & 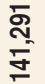 \\
\hline & 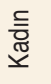 & $\stackrel{\mathscr{O}}{-}$ & $\begin{array}{l}\text { 足 } \\
\text { N }\end{array}$ & $\begin{array}{l}\text { Dे } \\
\text { ণ }\end{array}$ & $\begin{array}{l}\text { ?f } \\
\text { ल) }\end{array}$ & ָ̃ & $\begin{array}{l}\text { ర్ } \\
\text { ¿ }\end{array}$ & $\begin{array}{l}\text { W్ } \\
\text { N } \\
\text {. }\end{array}$ & $\begin{array}{l}\text { ల్ల } \\
\text { N }\end{array}$ & $\begin{array}{l}\hat{\circ} \\
\stackrel{-}{-}\end{array}$ & 0 & $\begin{array}{l}\text { ษે } \\
\text { ลี }\end{array}$ \\
\hline \multirow{3}{*}{ 苂 } & 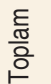 & $\begin{array}{l}\text { ô } \\
\text { N } \\
\text { I }\end{array}$ & $\begin{array}{l}\mathscr{\infty} \\
\stackrel{0}{=} \\
\text { N- }\end{array}$ & $\begin{array}{l}\text { Dे } \\
\text { Dे } \\
\text { Dे }\end{array}$ & $\begin{array}{l}\hat{N} \\
\stackrel{\infty}{N}\end{array}$ & $\begin{array}{l}\overline{0} \\
0 \\
0\end{array}$ & 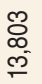 & $\begin{array}{l}\text { 导 } \\
0 \\
\infty \\
0\end{array}$ & $\begin{array}{l}\underset{N}{N} \\
\underset{c}{\infty}\end{array}$ & $\frac{\infty}{\infty}$ & $\begin{array}{l}\text { ̊े } \\
\stackrel{-}{\mp} \\
\text { F }\end{array}$ & 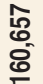 \\
\hline & $\begin{array}{l}\text { बै } \\
\text { 岦 }\end{array}$ & 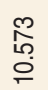 & $\begin{array}{l}\hat{\sigma} \\
\sigma \\
\sigma\end{array}$ & $\begin{array}{l}\mathscr{O}_{0} \\
\infty \\
\infty\end{array}$ & $\begin{array}{l}8 \\
\& \\
\sigma \\
\sigma\end{array}$ & $\frac{\widetilde{\sigma}}{\sigma}$ & $\begin{array}{l}\text { : } \\
\text { ㅁ } \\
\end{array}$ & 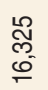 & 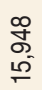 & $\begin{array}{l}\stackrel{\infty}{\sim} \\
\stackrel{\sim}{\sim}\end{array}$ & $\begin{array}{l}\text { స్ } \\
\text { ㅇ }\end{array}$ & $\begin{array}{l}\text { ष्ठ } \\
\frac{-}{+}\end{array}$ \\
\hline & $\begin{array}{l}\text { 号 } \\
\text { ฯ }\end{array}$ & $\underset{⿱}{\stackrel{+}{\leftarrow}}$ & $\begin{array}{l}\text { \& } \\
\stackrel{\sim}{*}\end{array}$ & $\begin{array}{l}\text { Dे } \\
\text { N }\end{array}$ & 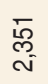 & 惢 & $\begin{array}{l}\text { D } \\
\text { - }\end{array}$ & $\begin{array}{l}\text { ని } \\
\text { N }\end{array}$ & 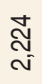 & $\begin{array}{l}\stackrel{\circ}{\circ} \\
--\end{array}$ & $\stackrel{\stackrel{?}{L}}{\stackrel{L}{-}}$ & $\begin{array}{l}\hat{E} \\
\text { So } \\
\text { o. }\end{array}$ \\
\hline \multirow{3}{*}{ ำ } & 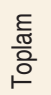 & $\begin{array}{l}\stackrel{8}{+} \\
\text { ㅇ }\end{array}$ & 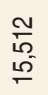 & $\begin{array}{l}\bar{\delta} \\
\stackrel{0}{-}\end{array}$ & $\begin{array}{l}\underset{\mathscr{\sigma}}{2} \\
\infty^{-}\end{array}$ & $\begin{array}{l}\stackrel{0}{\notin} \\
\stackrel{-}{=}\end{array}$ & $\begin{array}{l}\bar{E} \\
\stackrel{0}{0}\end{array}$ & $\begin{array}{l}\text { g } \\
\text { L }\end{array}$ & 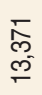 & 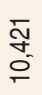 & 0 & 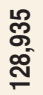 \\
\hline & $\begin{array}{l}\text { 产 } \\
\text { 岦 }\end{array}$ & $\frac{\stackrel{\circ}{\circ}}{\sigma}$ & $\begin{array}{l}\bar{y} \\
\dot{\forall}\end{array}$ & $\begin{array}{l}0 \\
0 \\
0 \\
6\end{array}$ & $\begin{array}{l}\text { ஜ } \\
\stackrel{-}{-}\end{array}$ & $\begin{array}{l}\text { ఖ్ } \\
\text { ণ্ } \\
\text { - }\end{array}$ & $\frac{\frac{L}{ \pm}}{\sigma^{-}}$ & $\begin{array}{l}\hat{\infty} \\
\infty \\
\stackrel{-}{\sim}\end{array}$ & $\stackrel{\stackrel{\circ}{\circ}}{=}$ & $\frac{\delta}{\sigma}$ & 0 & $\begin{array}{l}\text { oे } \\
\text { ㅇ } \\
\stackrel{5}{=}\end{array}$ \\
\hline & 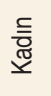 & 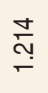 & $\underset{\sim}{\stackrel{T}{f}}$ & 导 & : & 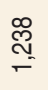 & $\stackrel{0}{\underline{n}}$ & ஜ̊ & $\underset{\leftarrow}{\check{\tau}}$ & ్ㅗㅀ & 0 & $\begin{array}{l}\text { ષ్రి } \\
\text { ల్ }\end{array}$ \\
\hline \multirow{3}{*}{ ஸ̃ } & $\begin{array}{l}\frac{E}{\mathbb{I}} \\
\frac{0}{0} \\
ㅇ\end{array}$ & 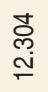 & $\begin{array}{l}\stackrel{8}{\circ} \\
\stackrel{\infty}{=} \\
=\end{array}$ & $\begin{array}{l}\hat{\tilde{O}} \\
0 \\
0\end{array}$ & $\begin{array}{l}\text { প్ల } \\
\text { के }\end{array}$ & 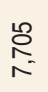 & 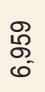 & $\begin{array}{l}\text { o } \\
\text { o } \\
\text { - }\end{array}$ & $\begin{array}{l}\stackrel{\mathscr{D}}{\mathbf{~}} \\
\infty\end{array}$ & 0 & - & \begin{tabular}{l}
$\bar{T}$ \\
d \\
\multirow{N}{*}{}
\end{tabular} \\
\hline & 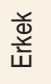 & 苂 & 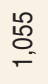 & : & 守 & $\frac{0}{\Gamma}$ & 员 & 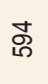 & $\overline{8}$ & 0 & 0 & 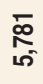 \\
\hline & $\begin{array}{l}\text { 듬 } \\
\text { エ }\end{array}$ & $\begin{array}{l}\stackrel{\circ}{+} \\
\stackrel{+}{\leftarrow}\end{array}$ & 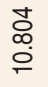 & $\begin{array}{l}\text { \&ै } \\
\text { 心) }\end{array}$ & 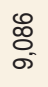 & $\begin{array}{l}\text { : } \\
\% \\
6\end{array}$ & $\begin{array}{l}\text { 宋 } \\
\text { ć }\end{array}$ & ঙ্লু & & & & \\
\hline 으 & 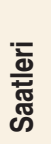 & $\begin{array}{l}\text { 芯 } \\
\text { ผ } \\
-\end{array}$ & $\begin{array}{l}\mathbf{W} \\
\text { 心 } \\
\text { N }\end{array}$ & 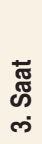 & $\begin{array}{l}\text { 胥 } \\
\text { के } \\
\text { + }\end{array}$ & $\begin{array}{l}\text { 芯 } \\
\text { की } \\
\text { ம }\end{array}$ & $\begin{array}{l}\text { त्ञ్ } \\
\text { के } \\
\text { ம. }\end{array}$ & $\begin{array}{l}\text { 芯 } \\
\text { હ } \\
\text { N }\end{array}$ & 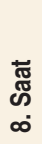 & $\begin{array}{l}+ \\
\text { 芯 } \\
\text { 心 } \\
\text { o. }\end{array}$ & 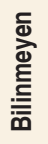 & 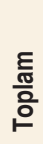 \\
\hline
\end{tabular}


Bu tabloda birinci iş saati 08.00-08.59, 9. iş saati 17.00-17.59'u kapsamaktadır; 12.0012.59 dâhil edilmemiştir. Şantiyelerde ve Toplumsal alanlarda birçok farklı özelliğe sahip makine tipleri bulunmaktadır. Bu makine tiplerinin tümünü almak mümkün değil ama şantiyelerde kullanılanları genelleme yapmak istediğimizde aşağıdaki Tablo 9’da ki sıralama kullanılabilir.

Projelerin kazı aşamalarında birden fazla yapı makinasının çalışması çalışmakta olup her birinin yapı inşaatında farklı görevleri mevcuttur. Aşağıdaki Tablo 10'da Kazalar esnasında yapılan aktivitelerin oranlarının göstermektedir. [6]

Tablo 9. Yapı Makinaları Türleri ve Kaza Oranları [6]

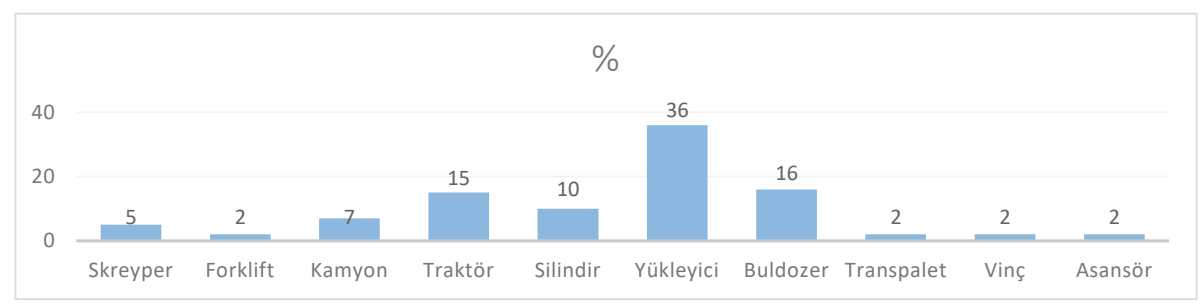

Tablo 10. Yapı Makinaları Türleri ve Kaza Oranları [6]

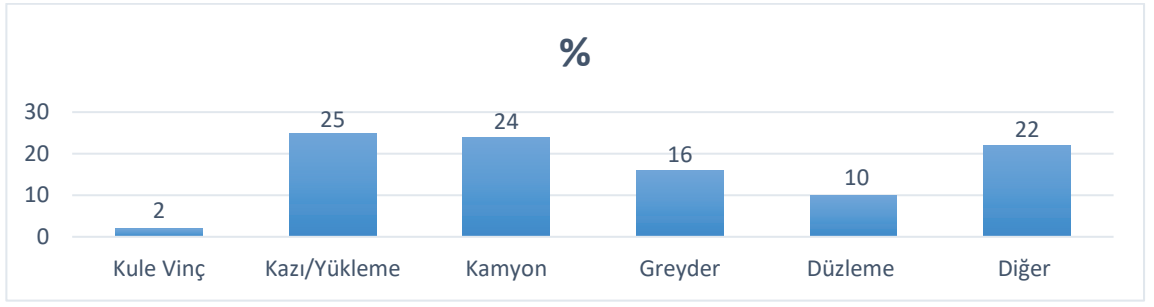

Farklı projelerde kullanılan farklı işlere göre mevcut makinalar bulunmaktadır. Yapı Makinaları kazalarının proje türlerine göre dağılımını incelemek istediğimizde proje tiplerine göre dağılımları aşağıdaki Tablo 11'de görebiliriz. 
Tablo 11. Ölümle ve Yaralanma ile Sonuçlanan Yapı Makinaları Kaynaklı Kazaların Proje Tiplerine Göre Dağılımı [6]

\begin{tabular}{|l|c|c|c|c|}
\hline \multirow{2}{*}{ Proje Tipi } & \multicolumn{2}{|c|}{ Ölümle sonuçlanan kazalar } & \multicolumn{2}{c|}{ Yaralanma ile sonuçlanan kazalar } \\
\cline { 2 - 5 } & \multicolumn{2}{|c|}{ Araçların Neden Oldukları } & \multicolumn{2}{c|}{ Araçların Neden Oldukları } \\
\cline { 2 - 5 } & Sayı & $\%$ & Sayı & $\%$ \\
\hline Bina & 33 & 16 & 24 & 24,7 \\
\hline Otoyol & 90 & 43,7 & 33 & 34 \\
\hline Diğer & 31 & 15 & 7 & 7,2 \\
\hline Kanal & 13 & 6,3 & 7 & 7,2 \\
\hline Baraj & 19 & 9,2 & 8 & 8,2 \\
\hline Enerji İletim & 7 & 3,4 & 1 & 1 \\
\hline Yıkım & 1 & 0,5 & 8 & 8,2 \\
\hline Köprü & 4 & 1,9 & 3 & 0 \\
\hline Demiryolu & 0 & 0 & 2 & 2,1 \\
\hline Liman & 6 & 2,9 & 2 & 2,1 \\
\hline Tünel & 2 & 1 & 2 & 2,1 \\
\hline Toplam & 206 & 100 & 97 & 100 \\
\hline
\end{tabular}

Yapı makinalarının risk değerlendirmesinin yapıldı̆̆ 1 bu çalışmada 108 operatör ve operatör yardımcısı ile birlikte bir anket çalışması yapılarak çalışanların görüşleri risk değerlendirmesi sürecine dâhil edilmiştir. Anketin yapılış amacı, operatör ve operatör yardımcılarının tecrübelerinden hareketle risk algılarını ve İSG alanına yaklaşımlarını kavrayabilmektir. Operatör ve operatör yardımcılarına yöneltilen 12 soru ile birlikte

Tablo 12. Operatör ve Operatör Yardımcılarının Çalıştığı Proje Türleri [6]

\begin{tabular}{|l|c|c|c|}
\cline { 2 - 4 } \multicolumn{1}{c|}{} & Frekans & Yüzde & $\begin{array}{c}\text { Kümülâtif } \\
\text { Yüzde }\end{array}$ \\
\hline Altyapı & 15 & 13,9 & 13,9 \\
\hline Yol-Köprü & 24 & 22,2 & 36,1 \\
\hline Baraj & 1 & 0,9 & 37 \\
\hline Konut & 22 & 20,4 & 57,4 \\
\hline Gökdelen & 10 & 9,3 & 66,7 \\
\hline AVM & 6 & 5,6 & 72,2 \\
\hline Diğer & 23 & 21,3 & 93,5 \\
\hline Birden fazla & 7 & 6,5 & 100 \\
\hline Toplam & 108 & 100 & \\
\hline
\end{tabular}
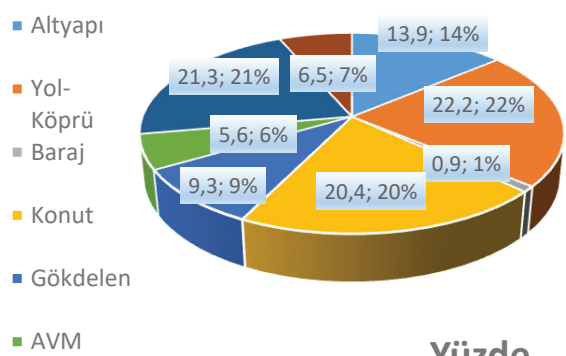

Yüzde 
yapı makinaları operatörlerinin bu alandaki görüşleri ve yaklaşımları kavranmaya çalışılmıştır. Yapı makinaları, bilindiği üzere tanımları ve işlevleri gereği bu proje tiplerinde daha ağırlıklı olarak kullanılmaktadır. Hemen hemen tüm alt yapı, yol-köprü projelerinde aynı anda birden fazla yapı makinası bir arada çalışmaktadır.[6]

Bilindiği gibi şantiyeler büyüklük tiplerine göre sınıflara ayrılmaktadır. Bu büyüklükler içinde barındırdığı çalışan sayıları ile de farklılıklar göstermektedir. Aşağıdaki Tablo13'te bu dağılım yapılan araştırma esnasında gezilen farklı şantiye tiplerindeki çalışan sayısı sınıflandırmasını görebiliriz.

Tablo 13. Operatör ve Operatör Yardımcılarının Çalıştığı Projedeki Çalışan Sayıları. [6]

\begin{tabular}{|l|c|c|c|}
\cline { 2 - 4 } \multicolumn{1}{c|}{} & Frekans & Yüzde & $\begin{array}{c}\text { Kümülâtif } \\
\text { Yüzde }\end{array}$ \\
\hline 50 'den az & 31 & 28,7 & 28,7 \\
\hline $50-99$ & 27 & 25 & 53,7 \\
\hline $99-200$ & 13 & 11,1 & 64,8 \\
\hline 200'den fazla & 38 & 35,2 & 100 \\
\hline Toplam & 108 & 100 & \\
\hline
\end{tabular}

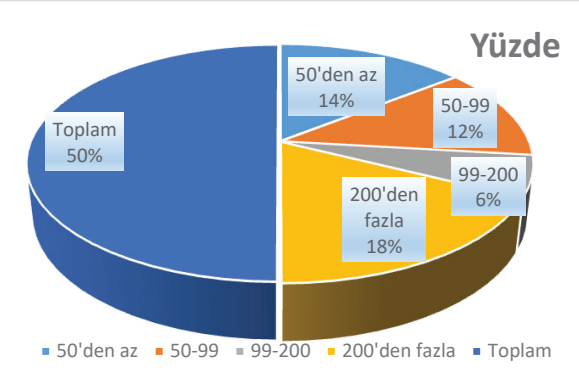

Projelerin küçük ya da büyük olma ölçeği bu ankette yalnızca çalışan sayısı ile değil proje ihale bedelleri gözetilerek belirlenmiştir. Buna göre; Tablo 14'de gösterilen küçük, orta, büyük, çok büyük olarak sınıflanan projelerdir. İhale bedeli 1 Milyon TL'den az olan projelere "küçük" projeler, 1-10 Milyon TL arasında olan projelere "orta" ölçekte projeler; 10-50 Milyon TL arasında olan projelere "büyük" projeler ve ihale bedeli 50 Milyon TL'den fazla olan projeler de “çok bü yük” projeler olarak tanımlanmıştır. [6]

Tablo 14. Operatör ve Operatör Yardımcılarının Çalıştığı Proje Büyüklükleri [6]

\begin{tabular}{|l|c|c|c|}
\cline { 2 - 4 } \multicolumn{1}{c|}{} & Frekans & Yüzde & $\begin{array}{c}\text { Kümülâtif } \\
\text { Yüzde }\end{array}$ \\
\hline Küçük & 34 & 31,5 & 31,5 \\
\hline Orta & 29 & 26,9 & 58,3 \\
\hline Büyük & 19 & 17,6 & 75,9 \\
\hline Çok Büyük & 26 & 24,1 & 100 \\
\hline Toplam & & & \\
\hline
\end{tabular}

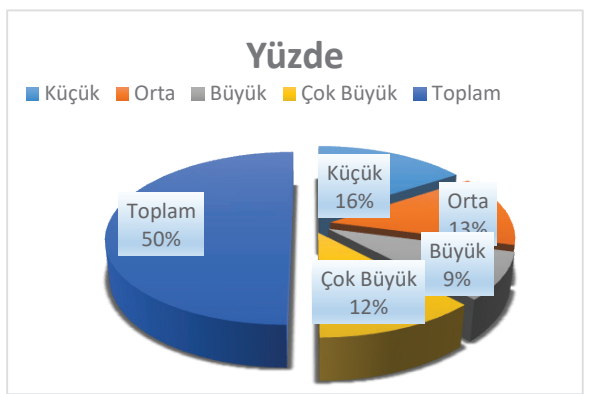


Hemen hemen büyük ve çok büyük çaplı inşaat projelerinin hepsinde farklı tip makinaların kullanıldığını daha önceden belirtmiştik. Bu tip projelerde kullanılan makine modelleri aşağıdaki Tablo 15 'te gösterilmeye çalışılmıştır.

Tablo 15. Operatör ve Operatör Yardımcılarının Şu An Kullanmakta Olduğu Makine Türü [6]

\begin{tabular}{|l|c|c|c|}
\cline { 2 - 4 } \multicolumn{1}{c|}{} & Frekans & Yüzde & $\begin{array}{c}\text { Kümülâtif } \\
\text { Yüzde }\end{array}$ \\
\hline Ekskavatör & 27 & 25 & 25 \\
\hline Dozer & 1 & 0,9 & 25,9 \\
\hline Loder & 3 & 2,8 & 28,7 \\
\hline Greyder & 3 & 2,8 & 31,5 \\
\hline Silindir & 4 & 3,7 & 35,2 \\
\hline Vinç & 30 & 27,8 & 63 \\
\hline Mikser & 1 & 0,9 & 63,9 \\
\hline Forklift & 4 & 3,7 & 67,6 \\
\hline Beko Y. & 11 & 10,2 & 77,8 \\
\hline Kamyon & 8 & 7,4 & 85,2 \\
\hline Beton mik. & 5 & 4,6 & 89,8 \\
\hline Diğer & 1 & 0,9 & 90,7 \\
\hline Birden Fazla & 10 & 9,3 & 100 \\
\hline Toplam & 108 & 100 & \\
\hline
\end{tabular}

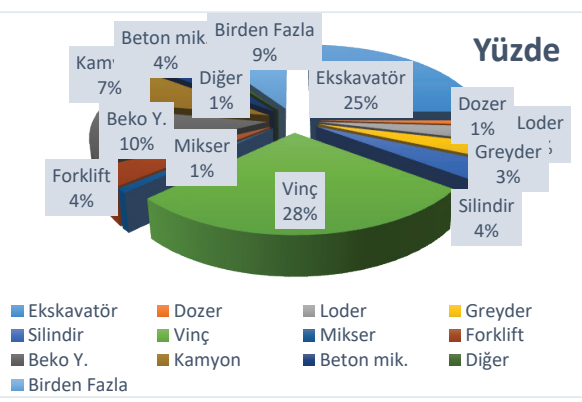

Tecrübe iş kazalarının azalmasında önemli bir faktördür. İş makinalarındaki kullanım tecrübesi dışında makinayı tanımakta kullanım kadar önemlidir. Aşağıdaki Tablo16' da konuşulan operatörlerin yıl bazında sahip oldukları tecrübeleri görülebilir.

Tablo 16. Operatör ve Operatör Yardımcılarının Yapı Makinasını Kullanma Süreleri (Tecrübe) [6]

\begin{tabular}{|l|c|c|c|}
\cline { 2 - 4 } \multicolumn{1}{l|}{} & Frekans & Yüzde & $\begin{array}{c}\text { Kümülâtif } \\
\text { Yüzde }\end{array}$ \\
\hline Bir yıldan az & 2 & 1,9 & 1,9 \\
\hline $1-5$ yıl & 30 & 27,8 & 29,6 \\
\hline $5-10$ yıl & 22 & 20,4 & 500 \\
\hline 10 yıldan fazla & 54 & 50 & 100 \\
\hline Toplam & 108 & 100 & \\
\hline
\end{tabular}

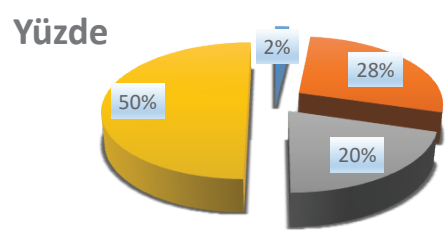

Bir yıldan az 1-5 yıl $\quad$ 5-10 yıl $\quad 10$ yıldan fazla

İş kazalarının engellenmesinde en önemli konu makinaların eğitimli operatörler tarafından kullanılmasıdır. Eğitim konusunda operatörlerden alınan cevaplara bakıldığında Tablo 17 aslında bize kaza sebepleri konusunda bilgi vermekte. 
Tablo 17. Operatör ve Operatör Yardımcılarının Makine Kullanmak İçin Eğitimi Aldıkları Yerler [6]

\begin{tabular}{|l|c|c|c|}
\cline { 2 - 4 } \multicolumn{1}{l|}{} & Frekans & Yüzde & $\begin{array}{c}\text { Kümülâtif } \\
\text { Yüzde }\end{array}$ \\
\hline Ustamdan & 47 & 43,5 & 43,5 \\
\hline $\begin{array}{l}\text { Özel eğitim } \\
\text { Kurumundan }\end{array}$ & 24 & 22,2 & 65,7 \\
\hline MEB'den & 17 & 15,7 & 81,5 \\
\hline Eğitim almadım & 20 & 18,5 & 100 \\
\hline Toplam & 108 & 100 & \\
\hline
\end{tabular}

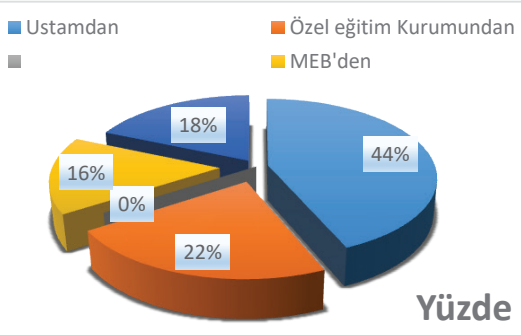

Peki, bu makinaları kullanan operatörlerin eğitim durumları nedir? Bu konu iş kazalarının oluşumunda etkili olabilir mi? Bu konuda verilen cevapları Tablo 18 de görmek mümkündür.

Tablo 18. Operatör ve Operatör Yardımcılarının Eğitim Durumu [6]

\begin{tabular}{|l|c|c|c|}
\cline { 2 - 4 } \multicolumn{1}{c|}{} & Frekans & Yüzde & $\begin{array}{c}\text { Kümülâtif } \\
\text { Yüzde }\end{array}$ \\
\hline İlkokul & 34 & 31,5 & 31,5 \\
\hline İlköğretim & 35 & 32,4 & 63,9 \\
\hline Lise & 38 & 35,2 & 99,1 \\
\hline Üniversite & 1 & 0,9 & 100 \\
\hline Toplam & 108 & 100 & \\
\hline
\end{tabular}

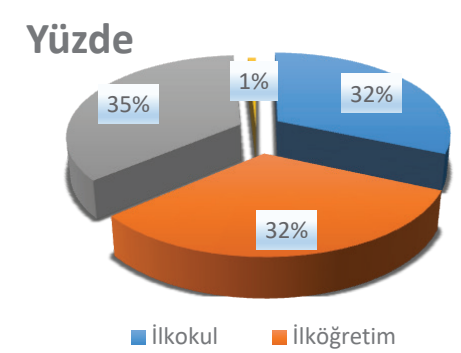

Operatör ehliyeti sahibi olmak günümüzde elde etmesi zor bir konu değildir. Yetkilendirilmiş kurumlar sayesinde bu sayı gün geçtikçe artmaktadır. Yapılan anket çalışmasinda verilen cevap oranı Tablo 19'da görülmektedir.

Tablo 19. Operatör ve Operatör Yardımcılarının Ehliyet veya Operatörlük Belgesine Sahip Olup Olmama Durumu [6]

\begin{tabular}{|l|c|c|c|}
\cline { 2 - 4 } \multicolumn{1}{c|}{} & Frekans & Yüzde & $\begin{array}{c}\text { Kümülâtif } \\
\text { Yüzde }\end{array}$ \\
\hline Var & 105 & 97,2 & 97,2 \\
\hline Yok & 3 & 2,8 & 100 \\
\hline Toplam & 108 & 100 & \\
\hline
\end{tabular}

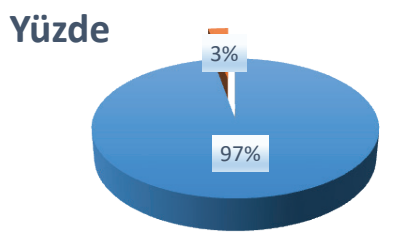

- Var $\square$ Yok 
İş makinası kullanan kişilerin sahip olması gereken belge(sertifika) ilgili makine modeline ait olması önemlidir. Kazıcı -Yükleyici iş makinası ehliyetine sahip bir operatörün şantiye içinde Greyder, Dozer, Teleskobik veya başka bir model makine kullanması yanlıştır. Greyder farklı bir sertifika gerektirir. Yetkili kurumlar tarafından verilen kurslar sayesinde alınan eğitimler farklı modeldeki makinaların o model hakkında eğitim almış kişiler tarafından kullanılmasını sağlar. Aynı operatörlerin sertifika almak dişında birde bu belgelerin ehliyetlerine işletilmesi hususu önemlidir. Tablo 20 'de bu oranla ilgili yapılan şantiye ziyaretlerindeki bir örnek çalışma verilmiştir.

Tablo 20. Operatör ve Operatör Yardımcılarının Sahip Olduğu Ehliyet Türü [ 6 ]

\begin{tabular}{|l|c|c|c|}
\cline { 2 - 4 } \multicolumn{1}{c|}{} & Frekans & Yüzde & Kümülâtif Yüzde \\
\hline E & 25 & 23,1 & 23,1 \\
\hline G & 52 & 48,1 & 71,3 \\
\hline A & 4 & 3,7 & 75 \\
\hline YOK & 2 & 1,9 & 76,9 \\
\hline Birden Fazla & 25 & 23,1 & 100 \\
\hline Toplam & 108 & 100 & \\
\hline
\end{tabular}

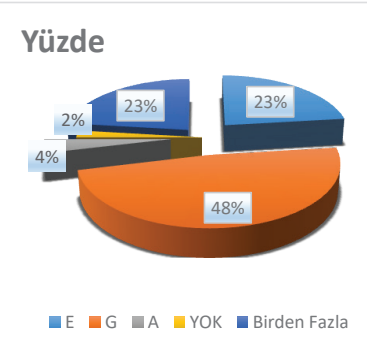

Ehliyet sadece makine kullanımı ile ilgili bir belgedir. Bunun dışında her operatörün muhakkak makinanın kullanımı, bakımlarını ve kullanım esnasında genel uyulması gereken İSG kuralları hakkında da eğitim alması önemlidir. Bu detayda Tablo 21'de görmektedir.

Tablo 21. Operatör ve Operatör Yardımcılarının ISG Eğitimi Alıp Almama Durumları [6]

\begin{tabular}{|l|c|c|c|}
\cline { 2 - 4 } \multicolumn{1}{c|}{} & Frekans & Yüzde & $\begin{array}{c}\text { Kümülâtif } \\
\text { Yüzde }\end{array}$ \\
\hline Aldım & 83 & 76,9 & 76,9 \\
\hline Almadım & 25 & 23,1 & 100 \\
\hline Toplam & 108 & 100 & \\
\hline
\end{tabular}

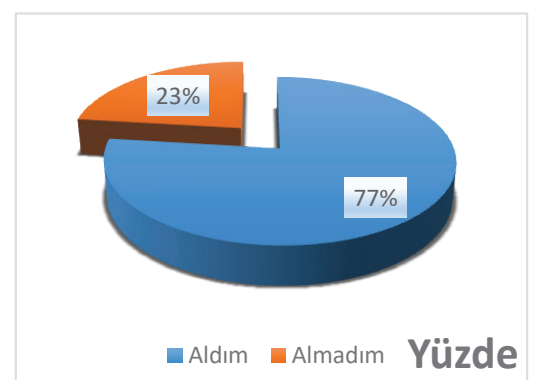

İş makinası kullanıcılarının kendilerinden başka çalışma ortamında ihtiyaç durumunda muhakkak işaretçilerle çalışması gerekir bu operatöre görmediği alanları görmeye ve kaza riskini azaltmaya yönelik önemli bir uygulamadır ve yönetmelik ve mevzuat detaylarında zorunluluk olarak belirtilmektedir. Bu durumun her geçen gün daha da yaygınlaşması ile İş makinası operatörlerinin kaza yapma olasılıkları azalacaktır. Şantiyelerdeki işaretçi sayısı hakkındaki oranla ilgili yapılmış bir şantiye sorgulaması Tablo 22'de görülmektedir. 
Tablo 22. Operatör ve Operatör Yardımcılarının İşaretçi ile Birlikte Çalışıp Çalışmama Durumu [6]

\begin{tabular}{|l|c|c|c|}
\cline { 2 - 4 } \multicolumn{1}{c|}{} & Frekans & Yüzde & $\begin{array}{c}\text { Kümülâtif } \\
\text { Yüzde }\end{array}$ \\
\hline Evet & 80 & 74,1 & 74,1 \\
\hline Hayır & 28 & 25,9 & 100 \\
\hline Toplam & 108 & 100 & \\
\hline
\end{tabular}

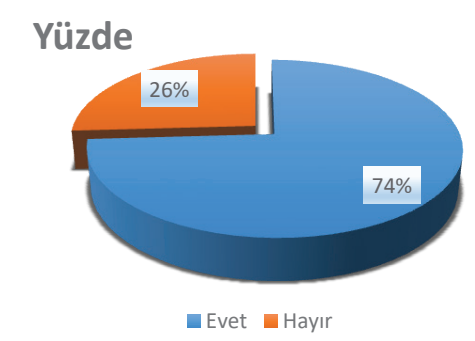

İş hayatına atılan inşaat mühendislerinin; iş makinaları, işçi sağlığı ve iş güvenliği hakkında bilmesi gerekli olan temel konuları öğreneceği asıl kaynak ise üniversitedir. Üniversitelerde iş makinaları, işçi sağlığ 1 ve iş güvenliği konularında verilen eğitimler bir inşaat mühendisinin bu konuya bakış acısını şekillendiren temel eğitimlerdir.

2011 yılında yapılan bir araştırmada Türkiye'deki 37 üniversitede yapılan bir araştırma ile İnşaat Fakültelerinin Lisans Ders İçeriklerinin Yapı Makinaları ve Yapı İşletmesi ile İşçi Sağlığı ve İş Güvenliği Acısından incelenmiş ve Tablo 23'teki sayılar bulunmuştur. Konu ile ilgili müfredatlar ders sayısı ve içeriği acısından incelendiğinde ve bir tasnif yapıldığında ilgili 37 üniversitenin yalnızca 6 tanesi yeterli 19 tanesi kısmen yeterli ve 13 tanesi de yetersiz olduğu görülmüştür. Buna göre içeriğinde inşaat mühendislerinin saha organizasyonlarının nasıl yapıldığının işlendiği Yapı İşletmesi ve Şantiye Tekniği ile sahada can güvenliği acısından en önemli dersler olan İnşaat Makinaları ve İşçi Sağlığı ve İş Güvenliği derslerinin bir bütün olarak hak ettikleri değeri 6 üniversite hariç hiçbir üniversitede göremedikleri tespit edilmiştir. Günümüzde üniversitelerin mühendislik fakülteleri ile teknoloji fakültelerindeki mühendislik alanlarının hepsinde İSG dersi verilmesi zorunlu hale getirilmiştir. Herhangi bir dönem içinde haftada en az 2 saat olacak şekilde eğitim almaları sağlanmaktadır. $\mathrm{Bu}$ derslerin içindeki İnşaat ve Yapı makinaları kullanımı ve dikkat edilmesi gereken hususlar şantiye ortamlarında önemli birer konu olarak kabul edilmesi gerekmektedir.

Tablo 23. Özet Tablo [9]

\begin{tabular}{|l|c|}
\hline \multicolumn{1}{|c|}{ Ders } & $\begin{array}{c}\text { Veren } \\
\text { Üniversite } \\
\text { Sayısı }\end{array}$ \\
\hline Yapı İşletmesi & 25 \\
\hline Şantiye Tekniği & 17 \\
\hline Yapı Makinaları & 9 \\
\hline İş Sağı̆ğı ve İş Güvenliği & 13 \\
\hline
\end{tabular}

\section{Yüzde}

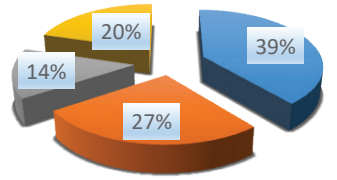

$$
\begin{aligned}
& \text { - Yapı İşletmesi } \quad \text { Şantiye Tekniği } \\
& \text { - Yapı Makinaları _ İş Sağlığı ve İş Güvenliği }
\end{aligned}
$$




\section{DEĞERLENDIRMELER}

1995 sonrası verileri meslek hastalıklarının tespit edilmesindeki sorunlara ilişkin ipuçları vermektedir. Veriler meslek hastalıklarının tespit edilmesi konusunda 1990'11 yıllara göre gerileme olduğunu göstermektedir. 1995-1999 döneminde yıllık olarak ortalama 167 meslek hastalığ 1 sebebiyle ölüm tespit edilmiştir. 2000 yılında meslek hastalığı tespiti sayısı önceki yıla göre \%20 azalırken ölüm tespiti sayısı birdenbire 6'ya düşmüş ve sonraki yıllarda bu seviyelerde sürmüştür. 6331 sayılı İSG sayısının yayınlandığı 2012 yılından sonra ise istatistiğe yansıyan meslek hastalığı tespitleri 0’a düşmüştür. Türkiye' deki çalışma ortamında ve sağlık sisteminde olağanüstü bir iyileşme olmadığına göre bu veriler 2000 yılından itibaren meslek hastalığı sonucu ölümlerin bilinçli ve sistematik olarak tespit edilmediğini göstermektedir. Veriler 5510 Md. 4-1/a kapsamındaki sigortalıları (işçileri) kapsamaktadır. Bağımsız çalışanlar bu tabloya dâhil edilmemiştir. 2017 yılında bağımsız çalışanlar için yayınlanan verilere göre 3 kişi iş kazalarında ölmüştür. 2017 yılında SSGSS kapsamında iş kazası sonucu ölüm toplam sayısı 1.636 kişidir. SGK istatistiklerindeki sayısal verilerin gösterildiği Tablo 1'den anlaşılmaktadır

Ölümle sonuçlanan kazalar arasında insan düşmesi tipindeki kazalar $(\% 42,9)$ önemli bir farkla ilk sırada yer almaktadır. Elektrik çarpması, malzeme düşmesi, yapı makinası kazaları, yapı kısmının çökmesi, şantiye içi trafik kazaları ve kazı kenarının göçmesi tipindeki olaylar ön plana çıkmaktadır. Toplam kaza sayısı bakımından \%11,5 oranıyla ikinci sırada yer alan ve kısaca Uzuv Kaptırma olarak tanımlanan olaylar, testerelere, tezgâhlara, hareketli makine elemanlarına el, parmak, ayak kaptırma tipindeki olaylardır. Sadece bir tanesi ölümle sonuçlanmış olmasına rağmen bu tür olaylar uzuv kaybına ve dolayısıyla çalışma gücünün belirli (bazen de önemli) oranda kaybedilmesine neden olarak Tablo 2'de görülmektedir.

Bina inşaatları için en önemli kaza tipinin insan düşmesi olduğu, özellikle ölümle sonuçlanan kazaların \%57,3'ünün bu şekilde meydana geldiği dikkati çekmektedir. Bina inşaatlarındaki yükseklik faktörü bunun başlıca nedenidir. Yine ölümle sonuçlanan kazalar arasında elektrik çarpması tipindeki olayların önemli bir orana $(\% 16,6)$ sahip olduğu Tablo 3'te dikkati çekmektedir.

Yol inşaatı şantiyelerinde Tablo 4 yapı makinalarının kullanımında meydana gelen kazalar ölümle sonuçlanan kazalar arasında \%39,6 oranıyla, toplam kazalar içinde de $\% 25,3$ oranıyla ilk sırada yer almaktadır. Yol inşaatlarının makine yoğun bir üretim olduğu dikkate alındığında bu sonucun doğal olduğu söylenebilir.

Kanal inşaatı şantiyelerindeki kaza tipleri Tablo 5'te verilmiştir. Bu uygulamalardaki tipik iş kazası olan kazı kenarının göçmesi olaylarının ilk sırada yer aldığı görülmektedir. Tüzük ve yönetmeliklerde kazı işlerine ilişkin ayrıntılı güvenlik önlemleri yer aldığı halde uygulamada bunların büyük ölçüde ihmal edildiği bir gerçektir. Açılan kanal çukurlarına insan düşmesi, kanal açmada kullanılan yapı makinalarının neden 
olduğu kazalar ve şantiye içi trafik kazaları ve kanalda çalışan işçiler üzerine malzeme düşmesi tipindeki olaylar kanal inşaatlarında öncelikle üzerinde durulması gereken kaza tipleri olarak dikkati çekmektedir.

Tünel inşaatlarındaki kaza tipleri Tablo 6'da görülmektedir. Tünel açma işlerinin niteliği gereği sıkça rastlanan, tünel tavanından malzeme düşmesi tipindeki olaylar ilk sırada yer almaktadır. Patlayıcı madde kazaları diğer önemli kaza tipidir.

2014-2018 yılları SGK istatistiklerine göre iş kazalarının meydana geldiği dönemler Tablo 7'de gösterilmiştir. Tablo 7'de de görüldüğü gibi 2014-2018 yılları arasında en çok iş kazasının meydana geldiği dönemler Mayıs-Aralık ayları arasında yoğunluk göstermektedir özelliklede İlkbahar-yaz ayları. Bunun sebebi; yaz döneminin inşaat sektörünün en verimli ve iş faaliyetlerinin fazla olduğu bir zaman dilimi olmasıdır. Yaz mevsiminde en çok iş kazası meydana gelmiştir. Yaz aylarındaki uzun çalışma saatleri ve sıcak havanın işçiler üzerindeki olumsuz etkileri bu duruma sebep olarak gösterilebilir.

2015 yılında gün içi mesai saatlerinde iş kazaları daha fazla yaşanmıştır. En fazla iş kazası yaşanan saatler ise sabah 09.00-11.59 (67 bin 26 kaza, yüzde 27,75), öğleden sonra 14.00-16.59 (55 bin 746 kaza, yüzde 23,08) saatleri ara-sındadır. 2016 yılında 286.068 iş kazası içinde 95 bin 704 (yüzde 33,45) kaza öğleye kadarki ilk dört iş saatinde; öğle iş saatinde (12.00-12.59) 14 bin 241 (yüzde 4,97); 100 bin 247 kaza (yüzde 35,04) öğleden sonraki beş iş saatinde yaşanmıştır. Sabah 08.00 ile akşamüstü 17.59 saatleri arasındaki iş saatlerinde toplam 210 bin 192 (yüzde 73,47) iş kazası yaşanmıştır. Gece 00.00 ile sabah 07.59 arasındaki iş saatlerinde 34 bin 411 (yüzde 12,02); akşamüstü 18.00 ile 23.59 arasındaki iş saatlerinde 41 bin 465 (yüzde 14,49) iş kazası yaşanmıştır. Özetle, 2016 yılında gün içi mesai saatlerinde iş kazaları daha fazla yaşanmıştır. En fazla iş kazası yaşanan saatler ise sabah 09.00-11.59 (80 bin 774 kaza, yüzde 28,23), öğleden sonra 14.00-16.59 (66 bin 722 kaza, yüzde 23,32) saatleri arasındadır. Tablo 8'de bu değerler net bir şekilde görülebilir.

Yapı makinaları türlerinin kaza sıklıklarının gösterildiği Tablo 9'da görüleceği üzere tüm kazalar arasında en büyük paya sahip olan araç türünün \% 36'l1k oranla yükleyici ve \% 16'l1k oranla dozer olduğu görülecektir. Yükleyicilerin hemen hemen tüm inşaat projelerinde en çok kullanılan yapı makinası olduğu düşülecek olursa yükleyiciye ait kaza oranının yüksek çıkması şaşırtıcı sayılmamalıdır. Sıklıkla kullanılan ve birçok işleve sahip olan yükleyiciler, aynı zamanda aşağıdaki grafikten de görüleceği üzere diğer makinalara göre daha çok kaza yapmaktadır.

Kazalar esnasında yapılan aktivitelerin oranlarının gösterildiği Tablo 10'da görüleceği üzere tüm kazalar arasında en büyük payı \% 25'lik oranla kazı ve yükleme aktiviteleri oluşturmaktadır. Projelerin kazı aşamalarında birden fazla yapı makinasının çalışmas1, çalışmaların genel olarak makinalar ile yürütülmesi vb. sebeplerden ötürü bu kaza türünün tüm kazalar içinde daha büyük bir paya sahip olduğu sonucu çıkartılabilir. 
Ayrıca en çok kaza yapan aracın yükleyici olması da kazı ve yükleme aktivitelerinin yüksek bir orana sahip olması ile bağlantılıdır. Kazı işlerinin dışında kamyonlar \% 24'le ikinci sırada gelirken greyder, dozer ve skreyperin yaptığı işlerden kaynaklı kazalar \% 16 ile dördüncü sıradadır

Yapı Makinaları kazalarının proje türlerine göre dağılımını gösteren Tablo 11'de, kazaların daha çok otoyol ve bina tipi projelerde yığılma gösterdiği anlaşılmaktadır. Bu durum da \%43,7 ile en yüksek orana sahip olan Otoyol Şantiyeleri İSG açısından binalara nazaran daha önemli bir alan olduğu ve dikkat edilmesi gereken bir çalışma sahasidir.

108 operatör ile yapılan anket çalışmasında operatörün çalıştığı proje tiplerinin öğrenilmesini amaçlayan soruya verilen cevapların gösterildiği Tablo 12'ye göre operatörlerin ağırlıklı olarak yol-köprü( $\% 22,2)$, konut $(\% 20,4)$ ve altyap1 $(\% 13,9)$ tipi projelerde çalıştıkları anlaşılmaktadır. Bu üç proje tipinin tüm projeler arasındaki toplam payı \%56,5'tir. Yapı makinaları, bilindiği üzere tanımları ve işlevleri gereği bu proje tiplerinde daha ağırlıklı olarak kullanılmaktadır. Hemen hemen tüm alt yapı, yol-köprü projelerinde aynı anda birden fazla yapı makinası bir arada çalışmaktadır

Hemen hemen büyük ve çok büyük çaplı inşaat projelerinin hepsinde en az bir adet kule vincin sabit olarak bulunduğu gözlenmiştir. O nedenle Tablo 15'deki oranlar arasındaki \%27,8'lik kule vinç operatörü oranı şaşırtıcı sayılmamalıdır. Benzer şekilde yalnızca kazı aşamasında değil kaba inşaatın devam ettiği sürelerde de ufak çaplı işler için kullanılan ekskavatör(\%25) ve beko yükleyici $(\% 10,2)$ inşaat projelerinde sık rastlanan yapı makinalarıdır.

Örnek bir çalışma olan 108 kişilik operatör anketinin özeti olan Tablo 16'dan anlaşılacağ1 gibi operatörlerin büyük çoğunluğunun tecrübeli olduğu söylenebilir. Bu verinin anketin büyük ölçekli projelerde uygulanması ile doğru orantılı bir bağı bulunmaktadir.

Yapılan ankette Tablo 17'de verilen "Ustamdan" cevabının oranın diğer sekmelere göre hissedilir derecede yüksek olması göstermektedir ki operatörlerin büyük çoğunluğu "yağcılık" diye tabir edilen ve operatör yardımcılığına denk düşen bir eğitimden geçmiştir. Herhangi bir akreditasyonu olmayan bu eğitim, tipik bir usta-çırak ilişkisine dayanmaktadır. Birkaç yıl boyunca deneyimli bir operatörün yanında gözlem yoluyla operatörlüğü kavrayan "yağcılar” bir süre sonra operatör olmak istediklerinde ilgili yapı makinasını kullanmak için edinmek zorunda oldukları ehliyet, sertifika vb. belgelerden dolayı eğitim kurumlarına yönelmektedir. Bu nedenle anket çalışmasına verilen cevaplar arasında \%43,5'le en fazla orana sahip olan "ustadan eğitim alma" durumu, aslına bakılacak olursa operatörlük belgesi olan operatörlerin nesnel algısını göstermektedir. Bunun yanında \%18,5'lik bir oranla “hiç eğitim almadığını” belirtenlerin oranı da dikkat çekicidir. 
Buna göre inşaatlarda çalışan işçiler arasında belirli bir seviye olarak kabul edilebilecek lise mezunlarının oranının Tablo 18'de operatörler arasında \%35,2 çıkması, operatörlerin inşaatlarda çalışan toplam içerisinde görece daha eğitimli çalışanlar olduğu sonucunun çıkarılmasına imkân vermektedir.

Ayrıca Tablo 19' da ve Tablo 20'de net bir şekilde görülüyor ki anketi cevaplayanların, \%97,2 gibi çok büyük bir oranla ehliyet ya da operatörlük belgesine sahip olmasının anketin uygulandığ 1 projelerdeki İSG uygulamalarına yaklaşımla doğrudan bağlantıs1 bulunmaktadır. 6331 sayılı İş Sağlığı ve Güvenliği Kanunu ve İş Ekipmanlarının Kullanımında Sağlık ve Güvenlik Şartları Yönetmeliğine göre bu bir zorunluluktur. Şantiyelerde kullanılan iş makinalarının o iş makinası modelini kullanmaya yetkin kişiler tarafından kullanılması iş kaza riskini de azaltacaktır.

Operatörlerin 2/3'ü inşaatlarda verilen bu tipteki İSG eğitimlerine katıldığı Tablo 20 ve Tablo 21'de net bir şekilde görülmekte. Bu başlıktaki bir başka veri de \% 87,1 oranıyla operatörlerin İSG eğitimlerini gerekli gördüklerini belirtilmiş olmalarıdır. $\mathrm{Bu}$ oranlar, yeterli olmasa da operatörlerin ISG uygulamalarına olan yaklaşımlarının anlaşılması bakımından önemli veriler sunmaktadır.

İş makinalarının kullanımı ile alakalı önemli bir eksiklik de işaretçi ve mevcuttaki işaretçilerin eğitim eksiklikleridir. Genel olarak işaretçi kullanılmamakla birlikte, kullanıldığı zaman bu işaretçilerin vasıfsız işçilerden seçildiği görülmektedir. 2013 yılında revize edilerek yayınlanmış olan İş Ekipmanlarının Kullanımında Sağlık ve Güvenlik Şartları Yönetmeliğine göre tehlike ihtiva eden ve bir operatörün hâkimiyetinde kullanılan ekipmanın yönlendirilmesi için işaretçi bulundurulması bir zorunluluktur o nedenle bu işçilere şantiyede iş güvenliği uzmanı tarafından işaretçi eğitimi verilmelidir. Pek çok şantiyede bu konuya önem verilmediğinden ve eğitimsiz kişilerin işaretçi olarak seçilmesinden dolayı da iş kazaları meydana gelebilmektedir. Şantiyelerde işaretleme sisteminin de özenle yapılması gerekmektedir. Konulacak tabelalar belli bir düzen içerisinde; şantiyelerin kor noktalarını, tehlikeli yerlerini gösterebilecek ve çalışanların dikkatini çekebilecek yerlere yerleştirilmelidir. Bu yerleşimin yapılabilmesi için şantiyeden sorumlu olan A sınıfı İş güvenliği Uzmanının gerekli risk analizi çalışmasını yapıp tehlike ve olasılıklar üzerinde çalıştıktan sonra bu şekilde bir belirleme yapması gerekir. Bu konuda yapılan anket sonucu Tablo 22 gösteriyor ki bu husus İSG konuları ciddiye alınan şantiyelerde \%74,1 ile hiçte kötü olmayan bir seviyede tutulmakta ama yine de bu sayı daha da yükseltilmelidir.

Türkiye'de inşaat sektöründe sahada veya ofiste çalışan inşaat mühendislerinin çok büyük bir kısmı yalnızca lisans mezunudur. Özellikle sahada çalışan inşaat mühendislerinin iş makinaları, işçi sağlı̆̆ı ve iş güvenliği konuları ile çok daha fazla mesai harcadığı gerçeği göz önüne alındığında bu konuda bilmeleri gereken temel bilgilerden ne kadar haberdar oldukları sorusu akla gelmektedir. Öncelikle inşaat mühendisi 
bu konularda bilinç sahibi olmalıdır, ondan sonra işçi ve operatörlerini gerekli şekilde eğitmelidir. Bir inşaat mühendisi, kendisi gerekli bilince ve bilgiye sahip olmadığ müddetçe ondan işçi ve operatörleri eğitmesi beklenemez. Bu nedenle eğitimi verecek kişinin yalnızca İnşaat mühendisi olması veya eğitimli olması beklenmez. Eğitimi verebilmesi için o firmanın A sınıfı iş güvenliği uzmanının olması gerekir. Aksi takdirde verilen eğitimler 6331 sayılı İş sağlığ 1 ve Güvenliği kanunu ile Çalışanların İş Sağlığı ve Güvenliği Eğitimlerinin Usul ve Esasları Yönetmeliğinde belirtilen çok tehlikeli iş yerlerinde her çalışan için yılda en az 16 saat İSG eğitimi verilme zorunluluğunun yerine getirilmediğini gösterir

Çok büyük bir kısmı yalnızca lisans düzeyinden mezun olup iş hayatına atılan inşaat mühendislerinin; iş makinaları, işci sağlığı ve iş güvenliği hakkında bilmesi gerekli olan temel konuları öğreneceği asıl kaynak ise üniversitedir. Üniversiteler de iş makinaları, işci sağlı̆̆ ve iş güvenliği konularında verilen eğitimler bir inşaat mühendisinin bu konuya bakış acısını şekillendiren temel eğitimlerdir. Tablo 23'te bu yönde 2011 yılında yapılan bir araştırma verileri görülmekte, Türkiye'nin 37 üniversitenin Yapı İşletmesi, Şantiye Tekniği, Yapı Makinaları, İşçi Sağlı̆ı ve İş Güvenliği derslerinin dağılımı incelenmiştir. Artan iş kazaları sebebiyle müfredatta yapılan değişiklik ile günümüzde üniversitelerin mühendislik fakülteleri ile teknoloji fakültelerindeki mühendislik alanlarının hepsinde İSG dersi almak zorunlu hale getirilmiştir. Bir dönem haftada en az iki saat olacak şekilde eğitim almaları sağlanmaktadır. Yapı İşletmesi ve Şantiye Tekniği dersleri ile sahada can güvenliği acısından en önemli dersler olan İnşaat Makinaları ve İSG derslerinin bir bütün olarak kabul edilmesidir. Bunun yanında Yapı İşletmesi ve Şantiye Tekniği derslerinin de birçok üniversitede yer almaması dikkat çeken başka bir husustur.

\section{4. ÖNERIILER}

İşçi sağlığ1 ve iş güvenliği konusu Türkiye'de hızlıca gelişen bir konu olmasına rağmen hala yapı makinaları kullanımından doğabilecek kazalara karşı alınabilecek önlemler konusuna önem verilmemektedir.

- İşsağlığı ve güvenliği hizmetleri bütün iş yerlerini ve tüm çalışanları kapsamalıdır. 6331 sayılı İş Sağlığı ve Güvenliği Kanununa göre çok tehlikeli, tehlikeli ve az tehlikeli tüm iş yerleri kapsam içerisindedir. Bu durum Bakanlık tarafından İSGKâtip sistemi üzerinden daha dikkatli denetlenmektir.

- İş yerlerinde kurulan İş Sağlığı ve Güvenliği birimleri göstermelik olmamalı, yasal olarak düzenlenip, yaptırım gücüne sahip olmalıdır, ayrıca özlük hakları yönünden işverene bağımlı olmamalıdır.

- Yen, sistemde İş Ekipmanlarının Kullanımında Sağlık ve Güvenlik Şartları Yönetmeliğine göre tüm iş ekipmanları ki iş makinalarının tümü üretici firma özel 
bir şart öngörmediği takdirde yılda bir kez teknik periyodik kontrolden geçirilmek zorundadır. Ayrıca bu durum da İSG Kâtip sistemi üzerinden denetlenebilmektedir. Saha sorumlularının bu kontrollere daha önem vermesi kaza riskini azaltacaktır.

- Şantiyelerde çalışan makine operatörlerinin kullandıkları makinalar ile ilgili teorik ve pratik eğitim almış olması gerekmektedir.

- Makina üzerinde ehliyetli operatörden başkası bulundurulmamalıdır.

- Çalışan odaklı bir iş sahası meydana getirmek için tüm işçi ve işverenin, yetkili kurum ve kuruluşlarca iş güvenliği konusunda bilinçlendirilmesi çalışmaları yapılmalıdır.

- Yaptığı işin bilincinde, iş sağlığı ve güvenliği konusunda bilgi sahibi işçiler çalıştırmak için belli aralıklarla meslek içi eğitimler verilmeli ve iş güvenliği konusunda çalışmalar yapılmalıdır.

- Kullanılan yapı makinaları ile ilgili yetkili kişilerden belli periyotlarda makine kullanımı ile ilgili eğitimler planlanmalıdır.

- Üniversitelerde kullanılan müfredatın güncel, sahada kullanılabilir ve dünya literatürüne uygun hazırlanması gerekmektedir.

- Tüm şantiyelerde zorunlu hale getirilen çalışan işçi ve teknik personele düzenli olarak İSG eğitimi verme olası iş kazalarını en aza indirgenmesinde önemli rol oynayacaktır. Bu eğitimlerde sahada iş makinaların da kullanarak uygulama yapmak ve bu eğitimlerde işaretçilerin önemine dikkat çekilmesi gerekmektedir.

- Şantiyelerde çalışan işçiler genelde vasıfsız olduğundan geçici süre ile çalışmaktadırlar. Bu sebeple iş tanımına bakılmaksızın inşaatlarda çalışacak personelin her uzmanlık alanı için ayrı mesleki yeterlikler istenmelidir. Meslekti yeterlilik sınavlarında başarılı olan operatörler yetkin oldukları makine haricinde başka bir makine kullanmamalıdır.

- İşe başlanmadan önce yapılması gereken ilk eylem şantiye planlamasının hazırlanmasıdır. Şantiyede yapı makinaları tarafından kullanılacak yollar planlanırken, devam eden işlere engel teşkil etmeyecek bir yol planı oluşturulmalı ve makina parkıyla makina ihtiyacının karşılanacağı alan arasındaki ulaşım rahat bir şekilde sağlanabilir olmalıdır.

\section{SONUÇ}

İş Sağlığı ve Güvenliği konusu günümüzde göz arda edilmeyecek bir konudur. Türkiye ekonomisinin lokomotifi olan inşaat sektörü ve yol inşaatları, bu alanda kullanılan yapı makinalarının şantiyelerde yarattığı tehlike dikkatten kaçmamalıdır. İnşaat şantiyelerinde mesleki yeterliği olan işçiler çalıştırılmalı, şantiye sahalarında çalışan iş makinaları personelleri kullandıkları iş makinaları ile ilgili ehliyet ve sertifika sahibi olmalıdır. Sahada ve belirli periyodlarda operatörler ve çalışanlar makinaların yarattığı tehlikeler konusunda bilgilendirilmelidir. Şantiyelerde çalışan mühendislere lisans 
eğitimleri sırasında iş sağlığı ve iş güvenliği konusu hakkında eğitim verilmeli bu konuda eğitim veren üniversite sayısı arttırılmalıdır. Verilen ders içeriklerinin başta Türkiye'ye şartlarında yaşanan kazaları kapsamalı, dikkat edilmesi gereken önlemleri vurgulamalıdır. Ayrıca bu kitapların içerikleri dünya standartlarında uygulanan iş güvenliği çözümlerini de içermelidir.

İş kazaları ve meslek hastalıkları, çalışanlar ve işletme açısından önemli bir maliyet unsuru olup çalışan ve örgüt verimliliğini olumsuz etkilemektedir. İş kazaları ve meslek hastalıkları sonucunda meydana gelen maddi ve manevi kayılar, aynı zamanda ülke ekonomisi için de büyük zararlara yol açmaktadır. Bu nedenle, işletmelerde iş kazası ve meslek hastalıklarına yol açan nedenlerin tespit edilmesi, gereken önlemlerin alınması ve denetlenmesi, daha sağlıklı ve huzurlu bir örgütsel ortamda etkin ve verimli bir şekilde çalışabilmek için temel gerekliliklerden biridir. İş kollarına ve sektörlere göre değişse de genel olarak iş yerlerinde alınması gereken önlemler üç başlıkta toplanabilir; çalışanlarla ilgili önlemler, iş yeri bölümleri ile ilgili önlemler ve iş ekipmanları ile ilgili alınacak önlemler.

$\mathrm{Bu}$ üç konuda işyerinde genel kontrollerin uzmanlar tarafından yapılması, eksikliklerin belirlenmesi ve iş mevzuatı uygulamalarına tamamen uyulması gerekmektedir. İncelenen vakalarda çok net bir şekilde ortaya çıkan sonuç, en basit ve en temel iş güvenliği önlemlerinin alınmamasının yüzlerce işçinin ölümüne neden olduğunu göstermesidir. En temel 6 kaza tipi (düşmeler, malzeme düşme/çarpma/sıçrama, elektrik çarpmaları, kazı kenarı göçükleri, yapı kısmı çökmesi ve yapı makinaları kazaları) toplam ölümlerin neredeyse çoğunluğunda karşımıza çıkmaktadır. Özetle ölüm ve yaralanmaların nasıl önleneceği kesinlikle bir bilinemez değildir ve her şey gün gibi ortadadır. Konuyla ilgili mevzuatın yetersiz olduğundan da söz etmek yanlış olacaktır. Mevzuatımızda ileri düzenlemeler yapılmış olmakla birlikte beklenen yararın sağlanabilmesi için toplumun her kesiminde iş sağlığ 1 ve güvenliği kültürünün geliştirilmesi çabalarına daha yoğun bir katkı gerekmektedir. Çocukluk çağından başlamak üzere ailede, okulda, hayatın her alanında sağlık ve güvenlikle ilgili eğitimler verilmelidir. Diğer yandan denetleme mekanizmasının etkinleştirilmesi büyük önem arz etmektedir. İşyerlerinin denetimi için konusunda yetkin denetmenlerin sayıları artırılmalıdır. Gerek işverenlerin gerekse iş sağlığ 1 ve güvenliği hizmeti veren firmaların sadece yasal yükümlülükleri yerine getirmek üzere kâğıt üzerinde anlaşma yapmaları ve çoğu firmaların bu yolu tercih ederek daha ucuza hizmet satın almaları, iş sağlığı ve güvenliği için en başta gelen tehditlerdendir. Bunun yanında yüksek kâr hırsı ile insan yaşamına verilen değerin neredeyse sıfır olması, inşaat üretiminin ve işgücünün yapısı ile birleştiğinde ortaya ölüm ve yaralanmalar çıkmaktadır. Bu ölümleri engellemek ise aynı zamanda bir mücadelenin konusu olup, inşaat işçilerinin örgütlülüğü bu bakımdan önem kazanmaktadır. Ülkemiz iş güvenliği ve sağlığı konusunda istatistiklere bakıldığında önceki yıllara göre iyileşme göstermektedir. Dileğimiz önümüzdeki yıllarda daha çok önlem alınması ve rakamlarda düşüşlerin görülmesidir. 


\section{KAYNAKÇA}

1. Müngen, M. U. 2011. “İnşaat Sektörümüzdeki Başlıca İş Kazaları”, Türkiye Mühendislik Haberleri,56/2011-5,say1469, sf32-39

2. Tan, O. 2007. “Şantiyelerde Oluşan Risklerin Değerlendirilmesi”, İSGİAD İŞGÜVENLİĞİ Dergisi, Ocak-Şubat-Mart, Y11 3, Sayı 9, sf1-7

3. Ercan, A. 2010،“Türkiye'de Yap1 Sektöründe İşçi Sağlığ1 ve Güvenliğinin Değerlendirilmesi”, Politeknik Dergisi, Cilt 13, SAYI 1, sf49-53.

4. Gürcanlı, G. E. 2008.“Dünyada ve Türkiye'de İş Güvenliğinde Gelinen Durum ve İnşaat Sektörü”, TMMOB Ölçü Dergisi, Şubat 2008 sayısı, Sf. 90- 98

5. Yalçın E., Taçgın E. 2016،“İnşaat Sektörü ve Kazı Uygulamalarında İş Güvenliği Önlemleri”, İnşaat Mühendisleri Odası (İMO) Bursa Bülteni, Sayı:65, Sayfa:9-11.

6. Uzun, İ. M. 2012. “İnşaatlarda Yapı Makinaları Kullanımında İş Güvenliği Risk Değerlendirmesi”, Yüksek Lisans, İTÜ Fen Bilimleri Enstitüsü, İstanbul

7. Yılmaz F., Tan O. 2015. "Bir İnşaat Şantiyesinde İş Kazalarının Neden Olduğu İş Günü Kayıplarının İşverene Maliyetinin Belirlenmesi”, International Journal of Economic and Administrative Studies, Year:7 Number 14, Winter 2015 ISSN 1307-9832, sf144156

8. Ulusal Meslek Standartı İş Makinası Bakım ve Onarımcısı Seviye 4.(2011). Mesleki Yeterlilik Kurumu, REFERANS KODU / 09UMS0010-4, RESMÎ GAZETE TARİH-SAYI / 26.05.2015 - 29367

9. Altınöz H., Uzun. M., Bahadır Y., Sarmusak F., Karagöz Y. 2011. "Yapı Makinaları Kullanımında Sıklıkla Karşılaşılan İş Kazaları ve Alınması Gereken Önlemler”, 3. İşçi Sağlığı ve İş Güvenliği Sempozyum, Çanakkale

10. Gürcanlı E. 2013. “Türk Tabipleri Birliği Mesleki Sağlık ve Güvenlik Derneği”, Sayfa: 20-29, Say1:48

11. Safe use of vehicles on construction sites: A guide for clients, designers, contractors, managers and workers involved with construction transport HSG144 HSE Books 1998 ISBN $071761610 \mathrm{X}$

12. Health and safety in excavations: Be safe and shore HSG185 HSE Books 1999 ISBN 0 717615634

13. 2018/12 "Isşçi-Sağlığı-ve-İş-Güvenliği-Raporu”, SHD İşçi Sağlığı ve İş Güvenliği Raporu, 13/12/2018, http://sosyalhaklardernegi.org/wp-content/uploads/2018/12/SHD-İşçiSağlığı-ve-İş-Güvenliği-Raporu_13.12.2018-2.pdf

14. http://www.tuik.gov.tr

15. http://www.sgk.gov.tr

16. http://www.csgb.gov.tr

17. HSE. 2018b. "Health and safety at work. Summary statistics for Great Britain 2018", http://www.hse.gov.uk/statistics/cost.htm 
18. Çelik, A. 2015. "İş̧̧i Ölümleri Bilinenin İki Kat1. Birgün”, 19.03.2015. https://www. birgun.net/haber-detay/isci-olumleri-bilinenin-iki-kati-80120.html, Erişim Tarihi: 22.11.2018) - ÇSGB. 2009. Ulusal İş Sağlı̆̆1 ve Güvenliği Politika Belgesi II 20092013.

19. ÇSGB. 2012. 6331 Sayılı İş Sağlığı ve Güvenliği Kanunu, Ankara. http://app.csgb.gov.tr/ isggm/guvenliiskele/IsSagligiveGuvenligiKanunu.pdf

20. Güven, R. 2012. "Dünyada ve Ülkemizde Meslek Hastalıkları”, web: www.hisam.hacettepe.edu.tr/calistaysunum/HavvaRanaGuven.pdf

21. HSE, 2018. "Healt and safety at work", ISBN 978-1-5286-1227-2, http://www.hse.gov. uk/statistics/overall/hssh1718.pdf

22. ILO. 2013. The Prevention of Occupational Diseases, ISBN 978-92-2-127447-6, 28/04/2013, https://www.ilo.org/wcmsp5/groups/public/---ed_protect/---protrav/--safework/documents/publication/wcms_208226.pdf

23. ILO. 2018. Improving Safety and Health of Young Workers, ISBN: 978-92-2-131651-0, https://www.ilo.org/wcmsp5/groups/public/---ed_protect/---protrav/---safework/documents/publication/wcms_625223.pdf 